\title{
Killing a second bird with one stone? Promoting firm capital growth and exports through tax policy
}

Citation for published version (APA):

Bernini, M., \& Treibich, T. (2016). Killing a second bird with one stone? Promoting firm capital growth and exports through tax policy. Industrial and Corporate Change, 25(5), 829-845. https://doi.org/10.1093/icc/dtw029

Document status and date:

Published: 01/10/2016

DOI:

10.1093/icc/dtw029

Document Version:

Accepted author manuscript (Peer reviewed / editorial board version)

\section{Please check the document version of this publication:}

- A submitted manuscript is the version of the article upon submission and before peer-review. There can be important differences between the submitted version and the official published version of record.

People interested in the research are advised to contact the author for the final version of the publication, or visit the DOI to the publisher's website.

- The final author version and the galley proof are versions of the publication after peer review.

- The final published version features the final layout of the paper including the volume, issue and page numbers.

Link to publication

\footnotetext{
General rights rights.

- You may freely distribute the URL identifying the publication in the public portal. please follow below link for the End User Agreement:

www.umlib.nl/taverne-license

Take down policy

If you believe that this document breaches copyright please contact us at:

repository@maastrichtuniversity.nl

providing details and we will investigate your claim.
}

Copyright and moral rights for the publications made accessible in the public portal are retained by the authors and/or other copyright owners and it is a condition of accessing publications that users recognise and abide by the legal requirements associated with these

- Users may download and print one copy of any publication from the public portal for the purpose of private study or research.

- You may not further distribute the material or use it for any profit-making activity or commercial gain

If the publication is distributed under the terms of Article $25 \mathrm{fa}$ of the Dutch Copyright Act, indicated by the "Taverne" license above, 


\title{
Killing a second bird with one stone?
}

\section{Promoting firm capital growth and exports through tax policy*}

\author{
Michele Bernini ${ }^{1}$ and Tania Treibich ${ }^{2}$ \\ ${ }^{1}$ National Institute of Economic and Social Research \\ ${ }^{2}$ Maastricht University, OFCE - Sciences Po and Sant'Anna School of Advanced Studies
}

May 1, 2015

\begin{abstract}
Does a lower tax rate on profits promote the international activity of small and medium enterprises? This paper addresses this question by exploiting a policy experiment in France. A reduction in corporate taxation is found to boost small and medium enterprises' capital growth and export participation. We estimate that a $50 \%$ reduction in the statutory tax rate induces, on average, a $29 \%$ increase in capital and a $6 \%$ increase in individual firms' probability of exporting. However, the estimated average treatment effect on the treated conceals substantial heterogeneity across firms with different initial productivity and size.
\end{abstract}

JEL classification: C21, C26, F14, H25, D24

Keywords: Export, Corporate Tax, Capital Growth, SME, Fiscal Reform

\section{Introduction}

Small and medium enterprises (SMEs) tend to be under-represented in international trade, despite their important contribution to countries' aggregate output and employment. It follows that their internationalization constitutes an important component of strategies to support growth in sluggish economies. However, consensus has yet to emerge regarding the effectiveness of different policies in achieving this objective, primarily due to the lack of empirical evidence that would permit robust causal inference. Drawing from a large-scale survey of European

${ }^{*}$ The authors would like to thank Flora Bellone, Richard Kneller, Francisco Requena-Silvente, Alessandro Sapio, Stefano Schiavo, Francesco Vona and two anonymous referees for the useful comments and suggestions. We would also like to thank Mark Beittel for proofreading the manuscript as well as GREDEG-CNRS for providing access to the data. All the remaining errors are our own. Emails: m.bernini@niesr.ac.uk, t.treibich@maastrichtuniversity.nl. 
companies, the EFIGE report recommends the removal of the institutional and fiscal barriers to firm growth as the most effective means of fostering SMEs' participation in foreign markets (Altomonte et al., 2012). Although this claim is motivated by the well-documented stylized fact that larger and more productive firms self-select into exporting (e.g, Bernard and Jensen, 1999), there is still a lack of micro-level empirical evidence on the impact of fiscal policy on SMEs' investment and export status.

The aim of this study is to fill this gap by exploiting the empirical setting offered by the 2001 French fiscal reform. It allows us to identify the impact of a reduction in corporate taxation $(\mathrm{CT})$ on SMEs' growth and export participation. Over the period 2001-2003, the French government reduced the corporate tax rate from $33.33 \%$ to $15 \%$ for SMEs' profits up to $€ 38,120$. The stated objective of this policy was to promote the growth of these companies and to remove their incentive to shield profits from taxation by using debt financing (Raspiller, 2007). Eligibility for the reduced tax rate depends on firm size, ownership and legal status, and it reflects the government's objective of targeting smaller and independent companies for this reduction. As a result, not all companies are affected by this policy, and it is possible to identify the 'treatment effect' of CT reduction by comparing treated and untreated companies.

We conduct our analysis on a dataset covering the population of French manufacturing firms over the period 1997-2007. We first assign the firms in our dataset to the treatment group and to various control groups. We then estimate a first Difference-in-Differences (DiD) model to identify the impact of CT reduction on total assets, capital and employment. This model compares the evolution of the outcome variables across different groups of firms before and after the reform. We check for the presence of confounding factors by estimating a second DiD model on the sample of treated firms. This second model identifies the treatment effect of the reform by exploiting the different extent to which the same reduction of the statutory CT rate entails different reductions of firm-specific effective tax rates (Egger et al., 2009). Having determined that the reform has had a positive impact on firms' capital growth, we exploit this policy shock as a quasi-experiment to identify the causal effect of capital growth on firms' export status by using Two-Stage Least Squares (2SLS) models. Specifically, a firm's eligibility for CT reduction is introduced as an instrument for capital growth in regressions on export status. 
The first contribution of the paper pertains to the vast literature on firm selection into exporting. Abundant empirical evidence has established that exporters are larger and more productive than non-exporters (e.g., Bernard et al., 1995; ISGEP, 2008) and that much of this difference can be attributed to self-selection of the best performers into foreign markets. Many studies from this literature attempt to establish causality between firm size and export status by exploiting the sequencing of firm investment to perform a Granger test of causality using longitudinal datasets. ${ }^{1}$ Because firms' strategies are inter-temporal and unobserved by researchers, this empirical approach does not convincingly address reverse causation between investment and export participation, and it does not identify the causal relationship between these two aspects of firm behaviour (Costantini and Melitz, 2008; Fabling and Sanderson, 2013). In other words, observing that larger and more capital-intensive firms tend to self-select into exporting or that investment in capital assets precedes export entry is not sufficient to establish that a policy promoting capital investment would be effective in fostering export participation. However, in our study, a consistent estimate of the causal relationship between firm capital and export status is obtained by exploiting the exogeneity of the fiscal shock caused by the reform with respect to firms' unobserved policies.

In addition, our work contributes to the fiscal literature on the impact of $\mathrm{CT}$ on investment. From a theoretical perspective, this literature predicts that, in the presence of decreasing returns to capital, CT exerts a negative effect on firms' investment (King and Fullerton, 1984; Devereux and Griffith, 1999, 2003). Empirical contributions have primarily tested this prediction at the macroeconomic level by exploiting cross-country differences in the effective average or marginal rates of taxation, defined as the difference between the return on capital in the presence and in the absence of taxation (e.g., Vartia, 2008; Bond and Xing, 2010). ${ }^{2}$ More recently, micro data have been used to compute firm-specific effective rates of taxation to investigate the heterogeneous impact of taxation on firms with different capital structures and asset compositions (Egger et al., 2009; Arnold et al., 2011; Fabling et al., 2013). Because our empirical setting is based on a policy

\footnotetext{
${ }^{1}$ See Wagner (2007) for a review of the studies adopting this methodology.

${ }^{2}$ Specifically, Bond and Xing (2010) exploit the cross-country variations in the statutory tax rates and the cross-industry variations in asset structures to model heterogeneous marginal costs of investment, while Vartia (2008) interacts statutory tax rates with industry-specific variables and is interested in changes in the average cost of investment.
} 
experiment, which allows us to control for both country- and firm-level confounding factors, we contribute to this literature by providing more solid evidence of a negative relationship between $\mathrm{CT}$ and investment in capital assets.

Our results suggest that lower corporate taxation promotes SMEs' capital accumulation and, through this channel, export participation. When comparing treated and untreated companies, we find that, on average, the reform caused a $6 \%$ increase in capital assets and, through this channel, a $1.4 \%$ increase in a firm's probability of exporting. This modest effect conceals an heterogeneous impact across treated firms. Indeed, when the analysis is restricted to small, treated firms, the average treatment effect rises to a $29 \%$ increase in capital assets and a $6 \%$ increase in export participation. Finally, we show that only the more productive firms within each industry, especially the smaller ones, benefit from CT reduction in the form of growth and export participation.

The remainder of the paper is organized as follows. Section 2 describes the empirical setting offered by the French fiscal reform and the identification of treated and untreated firms in the dataset. Section 3 illustrates the empirical strategy. Section 4 presents the results, and section 5 concludes.

\section{Empirical Setting and Data}

The introduction of a lower CT rate for French SMEs followed a general trend of tax reforms in industrialized countries initiated in the 1970s. These reforms were generally characterized by cuts in the statutory rates that were balanced by broadening the tax base. This made it possible to reduce the fiscal pressure on individual companies while allowing for stable levels of tax revenue (Devereux et al., 2002). In some instances, such as the UK and Canada, these reforms also introduced a more favorable tax regime for small companies, motivated by difficulty SMEs experience in accessing external finance and by their higher tax compliance costs (OECD, 1994). In the French case, the aim of the policymakers was to support investment, economic growth and job creation, as explained by the then Minister of the Economy Laurent Fabius in 
an article published by Le Monde. ${ }^{3}$

The 2001 fiscal reform was implemented in two steps. For eligible companies, the CT rate declined from 33.3 to $25 \%$ in 2001, and it was further reduced to $15 \%$ in 2002 . This reform was part of a long-term tax-reduction plan initiated by a reform in 1997 that first introduced lower profit taxation for SMEs. The 1997 and the 2001 fiscal reforms were promoted under both right- and left-wing governments, and their implementation appears to be disconnected from the political cycle.

For those companies that were already benefiting from the 1997 provision, the 2001 reform represented a less radical change in taxation. If they had already responded to the 1997 tax change with greater investment, the study of the 2001 reform in isolation may lead to an underestimation of the impact of CT reduction on investment. Nevertheless, we argue that this bias is likely small because the scope of the 1997 reduction is much narrower than that introduced in 2001. First, the eligibility conditions established in 1997 were more restrictive, causing the policy to affect a smaller proportion of firms. The 1997 reform restricted the pool of beneficiaries to firms with positive profits in the previous three consecutive fiscal years and required them to reinvest the full amount of money saved through lower taxation. Second, the 2001 reform generates greater tax gains for eligible firms, as it includes a lower tax rate compared to the previous reform (i.e., $15 \%$ versus $19 \%$ ) that applies to all profits below $€ 38,120$, while the 1997 reduction in the tax rate applied only to $25 \%$ of firms' profits up to a maximum of $200,000 \mathrm{~F}$ (i.e., $€ 30,500$ c.a.). The difference in depth and scope between the two reforms is confirmed by the fact that the average ratio of tax payments over profits plotted in figure 1 does not register the 1997 reduction, whereas it very clearly reflects the impact of the 2001 reform.

A different concern arises because other measures (i.e., cuts in employers' social contributions) had a timing similar to the policy of interest. Because these policies were not restricted to the group of firms treated by the 2001 CT reduction, a DiD approach is sufficient to disentangle the impact of lower profit taxation from confounding policies.

\footnotetext{
${ }^{3}$ Laurent Fabius, "Baisser les impôts pour préparer l'avenir" (Reduce taxes to prepare for the future), Le Monde, August 28, 2001.
} 


\subsection{The FICUS dataset}

The Fichier complet unifié de Suse (FICUS) is a panel database assembled by the French National Statistical Office (INSEE), and the coverage of the database approximates the universe of French firms for the period 1997-2007. FICUS integrates data on balance sheet items collected for fiscal purposes with survey data and provides information on over 4 million enterprises in manufacturing and services. ${ }^{4}$ The analysis is restricted to the manufacturing sector because this focus more closely conforms to the theoretical underpinnings of the hypothesis regarding the impact of CT reduction on firm growth and export status.

The time periods 1997-2000 and 2003-2007 are defined as the pre-treatment and posttreatment periods, respectively. Observations for the years 2001 and 2002 are excluded from the estimation sample. Because these two years represent a window of transition from the higher to the lower CT rates, they can neither be classified as pre- nor post-reform. In addition, the estimation sample includes only firms created before 2001 and surviving until at least 2003. This choice is made to prevent the downward bias in the estimated impact of the reform on firm size that arises if the lower rate of taxation fosters the entry of new and conceivably smaller companies into the group of eligible firms once the reduced rate is in place. In other words, the analysis focuses on the impact of a CT reduction on incumbent companies.

After cleaning, the final unbalanced sample comprises $1,105,764$ observations on 118,720 firms. Nominal values of balance sheet items are deflated by 2-digit industry-specific price indices provided by INSEE to obtain real values of firms' sales, total assets and tangible assets. ${ }^{5}$ By taking logs, we obtain the variables Assets and Tangibles. The variable Employees is computed as the log of the firm's average number of employees in each year. Finally, export status $(\operatorname{Exp}=1)$ is defined as firms' positive revenue from foreign sales. ${ }^{6}$

\footnotetext{
${ }^{4}$ FICUS excludes only firms that opt for the micro-BIC or the micro-BNC fiscal regimes. These firms have fewer than 10 employees and revenue below $€ 81,500$ (manufacturing) or $€ 32,600$ (services).

${ }^{5}$ As detailed in table 10 in the appendix, firms that change eligibility status for the CT reduction over the period of analysis are dropped, as are firms that are not liable to the CT that report positive tax expenses. The latter case may be observed because some legal statuses allow entrepreneurs to choose between income and corporate taxation.

${ }^{6}$ Further details on these variables are provided in table 11 in the appendix.
} 


\section{$2.2 \quad$ Identification of the treated firms}

The 2001 French Fiscal Law establishes the following conditions for firm eligibility for lower CT: (i) total revenue must not exceed $€ 7,630,000$, (ii) the firm's legal status should make it liable for corporate taxation (i.e., excluding firms liable for personal income taxation), and (iii) the majority shareholder of the company must not be a business group (DGI, 2002). Unfortunately, FICUS does not provide specific information on firms' CT regimes. We rely instead on a set of variables concerning legal status, affiliation to business groups and total revenue to identify firms that are eligible for CT reduction. ${ }^{7}$

Table 1: Descriptive statistics, 1997-2007, final sample.

\begin{tabular}{|c|c|c|c|c|c|c|}
\hline & \multirow[b]{2}{*}{ Nb. Firms } & \multirow[b]{2}{*}{ Nb. Obs. } & \multicolumn{2}{|c|}{ Tangibles } & \multicolumn{2}{|c|}{$\operatorname{Exp}$} \\
\hline & & & Mean & St.Dev. & Mean & St.Dev. \\
\hline All sample & 118,720 & $1,105,764$ & 4.485 & 1.849 & 0.187 & 0.390 \\
\hline All treated & 48,999 & 470,488 & 4.523 & 1.478 & 0.266 & 0.442 \\
\hline Treated below threshold & 41,560 & 395,599 & 4.298 & 1.404 & 0.229 & 0.420 \\
\hline Treated above threshold & 7,422 & 74,742 & 5.688 & 1.286 & 0.460 & 0.498 \\
\hline All untreated & 69,721 & 635,276 & 4.456 & 2.090 & 0.128 & 0.334 \\
\hline Business group & 3,553 & 23,189 & 6.493 & 1.660 & 0.514 & 0.500 \\
\hline Large & 7,029 & 63,854 & 8.995 & 1.514 & 0.828 & 0.377 \\
\hline Non-liable & 60,865 & 548,233 & 3.810 & 1.248 & 0.047 & 0.212 \\
\hline
\end{tabular}

We divide the full sample of ineligible firms into different subgroups on the basis of their unfulfilled eligibility condition. ${ }^{8}$ Untreated firms affiliated to a group are assigned to the 'Business group' control group, those with pre-reform average revenue above $€ 7,630,000$ to the 'Large' control group, and those with a legal status that is not subject to corporate taxation to the 'Non-liable' control group. In addition, the set of treated firms is divided in two subgroups, those with pre-reform average profits below and above the threshold of $€ 38,120$. Because the reduced tax rate applies only to profits below $€ 38,120$, companies below this threshold benefit

\footnotetext{
${ }^{7}$ Note that the affiliation to a business group condition is more restrictive than the letter of the fiscal law, according to which the 'independence' criterion is still satisfied if a single individual owns $75 \%$ of the business group controlling the firm. Unfortunately, the data do not provide such information. Nevertheless, the number of firms that are incorrectly identified as ineligible is not large enough to compromise the validity of the results. See table 11 in the appendix for details on the construction of all variables.

${ }^{8}$ Firms' compliance with the sales or profits thresholds is defined by using firm-level pre-reform averages of total sales and profits, instead of their annual values. This is done to exclude from the computation the effect of changes in these attributes that are due to firms' adaptation to the new fiscal regime.
} 
from the full $50 \%$ cut in the average and marginal statutory rates, both of which declined from $33.33 \%$ to $15 \%$. Table 1 presents descriptive statistics for Tangibles and Exp across these different groups. Eligible firms represent $41 \%$ of the firms in the sample. They are smaller than but twice as export-oriented as those in the overall control group, which is dominated by non-liable firms (87\%). However, the export propensity of non-eligible firms differs substantially across subgroups, ranging from 0.83 for the 'Large' firms to 0.05 for those included in the 'Non-liable' group.

\subsection{Computing the firm-specific tax-gain indicators}

The effect of taxation on investment depends on firms' ability to discount investment and interest expenses from taxable profits. Hence, asset composition and financial structure generate a different impact of taxation across firms. This heterogeneity is measured by the firm-specific marginal and average effective tax rates EMTR and EATR computed following Egger et al. (2009)..$^{9}$ The marginal and average effective tax gains $\triangle E M T R$ and $\triangle E A T R$ characterize the differential impact of the reform on treated firms:

$$
\begin{aligned}
\Delta E M T R_{i} & =\operatorname{EMTR}\left(\tau_{\text {pre }}\right)_{i}-\operatorname{EMTR}\left(\tau_{\text {post }}\right)_{i} \\
\Delta E A T R_{i} & =\operatorname{EATR}\left(\tau_{\text {pre }}\right)_{i}-\operatorname{EATR}\left(\tau_{\text {post }}\right)_{i}
\end{aligned}
$$

where the pre-reform statutory tax rate $\tau_{\text {pre }}=0.33$ for all firms, the post-reform statutory tax rate $\tau_{\text {post }}=0.33$ if the firm is untreated, $\tau_{\text {post }}=0.15$ if the firm is treated and the average pre-reform profits $\overline{A P_{i}}$ are below the threshold of $€ 38,120$, and $\tau_{\text {post }}=0.15 *\left(\frac{38,120}{A P_{i}}\right)+0.33 *$ $\left(\frac{A \bar{P}_{i}-38,120}{A \bar{P}_{i}}\right)$ if the firm is treated but its pre-reform average profits are above the threshold at which the reduced tax rate applies. ${ }^{10}$

Table 2 reports summary statistics for $\triangle E M T R$ and $\triangle E A T R$ for all eligible firms and for the two subgroups of treated firms. It becomes clear that only firms below the threshold benefit from a reduction in their marginal effective tax rate, as well as a greater change in average

\footnotetext{
${ }^{9}$ The appendix provides further details on the computation of the effective tax rates.

${ }^{10}$ The difference between the pre- and post-reform rates is taken instead of the more conventional difference between post- and pre-reform rates to obtain positive measures of tax gains that greatly facilitate the interpretation of regression results.
} 
effective taxation. This evidence conforms to the progressivity of the average statutory tax rate that responds to the primary aim of the policy to support the smallest firms (Raspiller, 2007).

Table 2: Tax gain from the reform within the group of treated firms.

\begin{tabular}{|c|c|c|c|c|}
\hline & \multicolumn{2}{|c|}{$\Delta \mathrm{EATR}$} & \multicolumn{2}{|c|}{$\Delta$ EMTR } \\
\hline & Mean & St.Dev. & Mean & St.Dev. \\
\hline All treated & 0.138 & 0.031 & 0.052 & 0.077 \\
\hline Treated below threshold & 0.149 & 0.013 & 0.063 & 0.081 \\
\hline Treated above threshold & 0.085 & 0.038 & 0.000 & 0.000 \\
\hline
\end{tabular}

Figure 1 depicts the evolution of the median 'backward' tax rate across treated and control groups (left panel) and among eligible firms divided by quartiles of pre-reform average profits (right panel) over the period considered. ${ }^{11}$

Figure 1: Evolution of the 'backward' tax rates

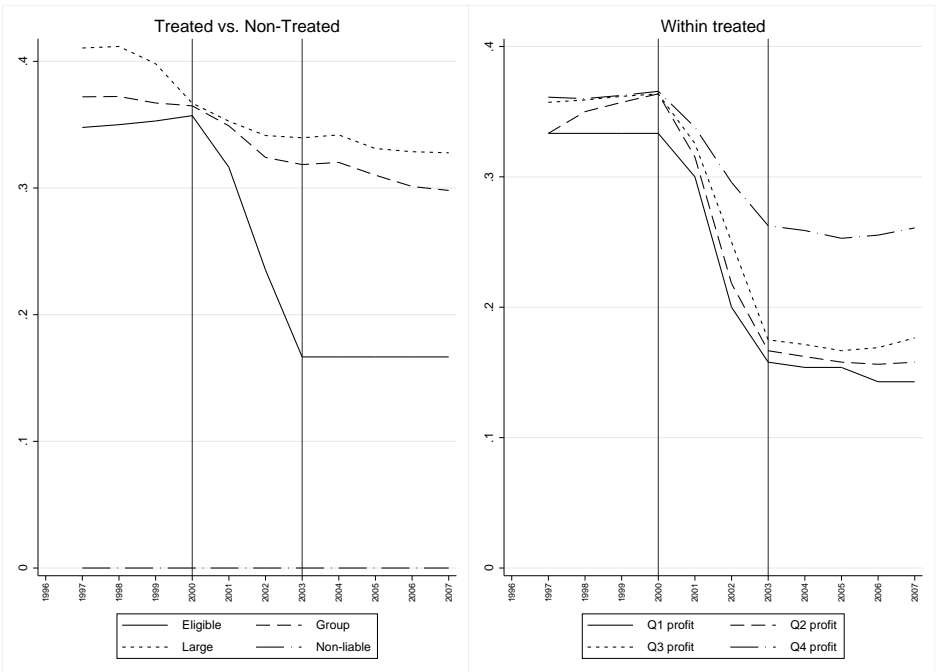

Notes. 'Backward' tax rates are computed at the firm level as the ratio of tax payments over gross profits. Each line plots the median of these rates computed at the group-year level. The left-hand side panel groups firms according to treatment status. The right-hand side panel represents the evolution of the median 'backward' rates computed for treated firms belonging to different quartiles of the profit distribution.

The sharp reduction in the median tax rate between 2001 and 2003 for the group of treated firms corroborates the strategy employed to identify the group of firms eligible for CT reduction. The smaller decrease observed for 'Large' and 'Business group' firms is explained by the fact that

\footnotetext{
${ }^{11}$ By adopting the terminology of Egger et al. (2009), 'backward' rates of taxation are defined as the rates obtained by dividing current tax payments by current gross profit. These rates are called 'backward' because they are the outcome of firms' past investment. Conversely, EMTR and EATR are defined as 'forward' rates because they measure the impact of taxation on firms' future investment.
} 
there was also a progressive cut in the social contribution tax that affected all firms liable for CT after 1999. These plots also motivate the choice to exclude the years 2001 and 2002 from Difference-in-Differences (DiD) regressions. By examining the 'Treated' line, it is clear that the last pre-reform and the first post-reform years are 2000 and 2003, respectively. Furthermore, the right panel of figure 1 shows that within the group of treated firms, the same reduction in the statutory rate entails heterogeneous changes in average taxation.

\section{Figure 2: Evolution of firm size and productivity}
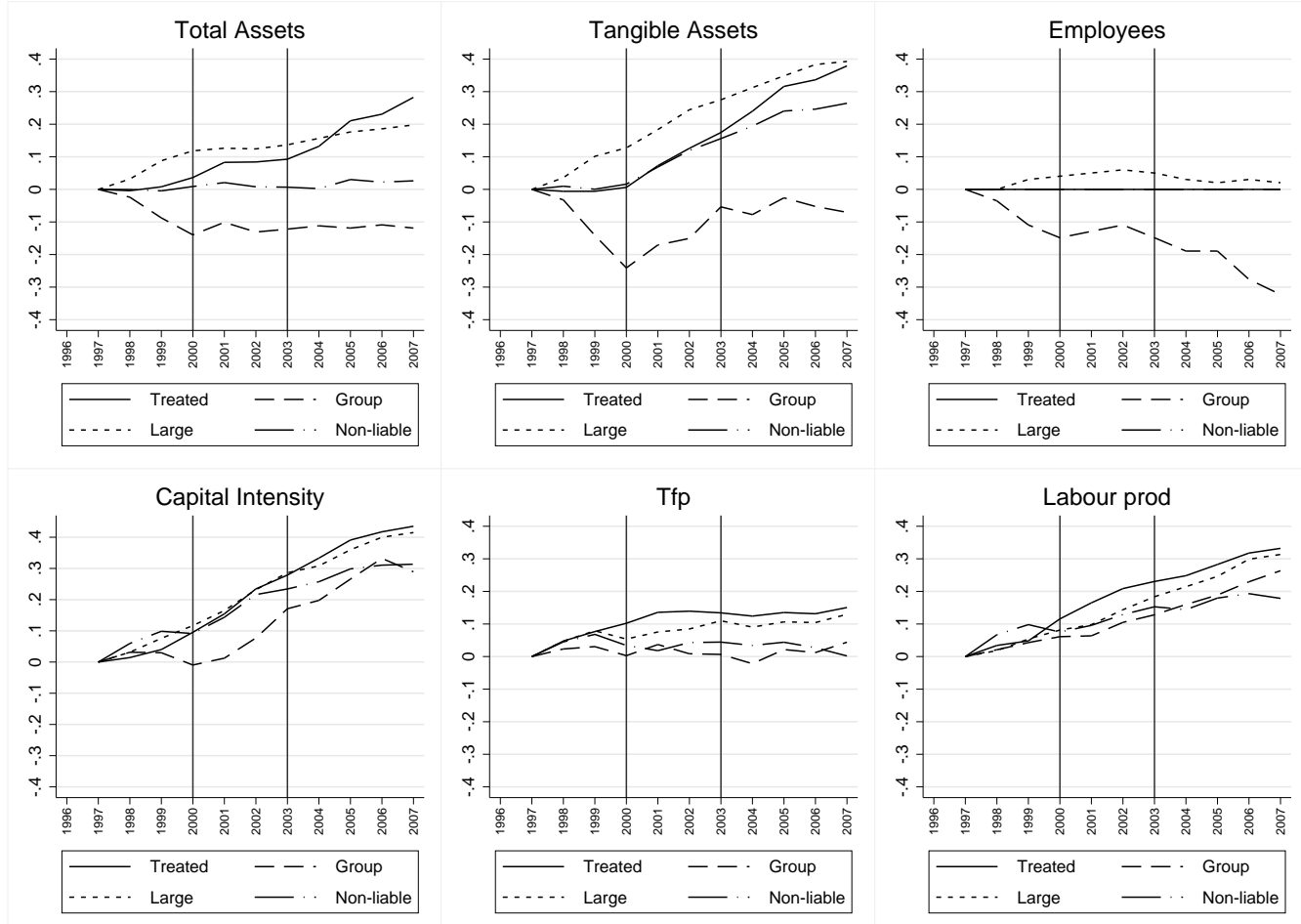

Notes. Panels plot the evolution of the median level of the firm-level variable computed at the group-year level. Because all variables except 'Capital intensity' are in logs, each series is normalized by taking the difference between the value at each point in time and its value in 1997 . The normalized series can then be interpreted as the cumulative growth since the initial period. The construction of the variables is detailed in table 11 in the appendix.

Figure 2 depicts the evolution of firm size and productivity measured by different standard indicators. Treated firms are those that experienced the fastest capital growth over the period (i.e., the evolution of tangible and total assets, as well as capital intensity). This is in line with the view that a reduction in corporate taxation increases the net present value of future investment projects because a smaller share of the income generated by capital goods is absorbed 
by taxation. Conversely, the evolution of the number of employees does not present a distinctive pattern across groups, suggesting that the reform may have not been as successful in promoting employment as was the case for capital growth. If the evidence of diverging trends before the reform suggests exercising caution in inferring causality, total factor productivity $(T f p)$ and labour productivity increased somewhat faster for the group of treated firms.

The graphical analysis is also used to identify the control groups for which the Common Trend Assumption (CTA) underpinning DiD is less tenable. This assumption requires that in the absence of treatment, treated and untreated firms would present the same dynamics (same trend). A control group for which the CTA is more likely to hold is that for which the pre-reform trend in the outcome variable more closely follows the trend of the treated group. Concerning size proxies, large firms and those that are part of a business group present a pre-reform trend that diverges from that of eligible firms, with the former growing more rapidly than eligible firms and the latter presenting a negative trend. However, non-liable firms appear to be appropriate counterfactuals because their pre-reform size dynamic is very similar to that of eligible firms.

\section{Empirical Strategy}

\subsection{Difference-in-Differences models on firm size}

The impact of a CT reduction on firm size is first identified by comparing the difference in the levels of total assets (Assets) and capital (Tangibles) and in the number of employees (Employees) before and after the reform for firms belonging to the treated group vis-à-vis those belonging to different control groups. Because Assets includes both permanent and current assets, it is the broadest measure of the three and also captures contingent variations in firms' sales. Tangibles measures firms' capital assets and can be regarded as the outcome of investment decisions made in previous periods. According to the fiscal literature, higher taxation reduces investment in capital assets, and hence Tangibles is the most theoretically grounded indicator available to trace the impact of taxation on firm size. Finally, the impact of the reform on Employees and Tangibles is compared to verify whether a CT reduction determines Hicksneutral technological change by affecting capital and labour in the same way (Hicks, 1932). 
Dependent variables in levels are used instead of first differences because they better reflect firms' investment and employment decisions made over a longer period of time, and they are less sensitive to inter-temporal substitution in the short term. ${ }^{12}$ This strategy is implemented via OLS estimation of a DiD model with firm fixed-effects. The first DiD model uses the following specification:

$$
Y_{i t}=\alpha+\gamma_{1}\left(\text { Treat }_{i} \times \text { Post }_{t}\right)+\theta_{i}+\delta_{t}+\epsilon_{i t}
$$

where $Y$ will be proxied by Assets, Tangibles or Employees, and Treat is a dummy variable that takes value one for treated companies and zero otherwise. Post is a dummy variable taking value zero or one in the pre- and post-reform periods, respectively. Firm-level fixed-effects $\theta$ control for time-invariant, firm-specific factors that determine differences in size across individual firms, forcing the identification of the parameter $\gamma_{1}$ on variations in size over time within the same firm. In addition, contingent macroeconomic shocks commonly affecting all firms are absorbed by time fixed-effects $\delta$, while $\epsilon$ is the error term. The coefficient $\gamma_{1}$ can be interpreted as the causal effect of the reform on firm size under the CTA:

$$
\begin{aligned}
\gamma_{1}= & \left\{\mathbb{E}\left[Y_{i t} \mid \text { Treat }_{i}=1, \text { Post }_{t}=1\right]-\mathbb{E}\left[Y_{\text {it }} \mid \text { Treat }_{i}=1, \text { Post }_{t}=0\right]\right\}- \\
& \left\{\mathbb{E}\left[Y_{i t} \mid \text { Treat }_{i}=0, \text { Post }_{t}=1\right]-\mathbb{E}\left[Y_{i t} \mid \text { Treat }_{i}=0, \text { Post }_{t}=0\right]\right\}
\end{aligned}
$$

Although it is not possible to formally test for the CTA, graphical evidence in figure 2 provides an indication of which control group constitutes the most appropriate counterfactual.

A different concern arises because the treated group is sufficiently large to include firms subject to unobserved policies or shocks, the timing of which overlaps with that of the CT reform. In this case, the first model may incorrectly attribute to the reform the effect of other factors on firm growth. This concern is addressed by estimating a second DiD model that identifies the impact of the reform by exploiting the heterogeneous reduction in the marginal and average rates of effective taxation $E M T R$ and $E A T R$ across small treated firms with pre-reform average

\footnotetext{
${ }^{12}$ In addition, figure 2 shows that for treated firms, a steeper growth of total assets and capital begins in the period 2001-2002 that is excluded from the analysis. Therefore, a comparison of the pre-reform and post-reform year-to-year growth rate of the dependent variables would not capture the increase in total and tangible assets occurring within this time window.
} 
profits below the $€ 38,120$ threshold. Above this threshold, the average statutory rate introduced by the reform becomes strongly progressive (i.e., it increases with the profitability of the firm), and lower rates of average taxation would reflect lower profitability and lower growth prospects. Instead, below this threshold, the rate of average taxation is constant and independent of average profitability, and hence heterogeneous effective rates across firms depend only on the firms' different capital structures and asset compositions and do not directly determine future growth. Therefore, firm-level heterogeneity in this sample is related to the intensity of the treatment (i.e., the reduction in effective taxation) but not to the growth potential of companies. The second DiD model has the following specification:

$$
Y_{i t}=\alpha+\gamma_{2}\left(\Delta T A X_{i} \times \text { Post }_{t}\right)+\theta_{i}+\delta_{t}+\epsilon_{i t}
$$

where $\triangle T A X$ is either $\triangle E M T R$ or $\triangle E A T R$. Because $\triangle T A X$ is a continuous variable, the impact of the reform on the asset growth of firm $i$ is given by $\gamma_{2, i}=\gamma_{2} \times \Delta T A X_{i}$. If the reform is effective in promoting growth, the coefficient $\gamma_{2}$ is positive and statistically different from zero because firms that enjoy greater reductions in effective rates should be more responsive to the policy.

\subsection{SLS model on export status}

Guided by the theories on corporate taxation and investment, the reduction of CT is exploited as an exogenous shock that affects firms' investments in capital assets (King and Fullerton, 1984; Devereux and Griffith, 1999, 2003) to investigate whether capital growth fosters export participation. A prolific empirical literature has established that larger and more capital-intensive firms self-select into exporting (e.g., Bernard and Jensen, 2004; Blum et al., 2013; Fabling and Sanderson, 2013). However, because both firm investment policy and export decisions are bound to depend on unobservable strategies, this literature does not provide a clear conclusion regarding whether a fiscal policy that promotes firm growth should be expected to foster export participation. We address this question by estimating a 2SLS model in which the first stage is the DiD model described above and the second-stage equation is a reduced-form linear probability 
model (LPM) of the relationship between firms' capital and export status:

$$
\operatorname{Exp}_{i t}=\beta+\zeta \text { Tan } \hat{g} i b l e s_{i t}+\theta_{i}+\delta_{t}+\epsilon_{i t}
$$

where Exp is a dummy variable taking value one if the firm is selling part of its output on foreign markets and Tangibles is the predicted level of capital from the DiD regression. ${ }^{13}$

Because the term Treat $\times$ Post (or $\Delta T A X \times$ Post) in the first-stage model on Tangibles is the instrument excluded from the second-stage model on Exp, the exclusion restriction requires that the reduction in corporate taxation exclusively affects export participation through its effect on firms' capital. It is important to note that the exclusion restriction does not imply any specific channel through which capital affects export participation. A positive shock to the level of capital may facilitate firm entry into exporting either by increasing firm-level productivity or by expanding a firm's scale of production. Although recent trade models attempt to disentangle the relative importance of these channels to explain the positive correlation between size and export status (Blum et al., 2013), this objective is beyond the scope of this paper.

\section{Results}

\subsection{Does CT reduction promote firm growth?}

Table 3 reports estimates from the first model (equation 1). Columns are grouped under the names of four different estimation samples obtained by including treated firms and firms belonging to different control groups. The control groups included in the samples are: all untreated firms in Untreated, non-independent firms in Business Group, firms above the size threshold for eligibility in Large, and firms non-liable for CT in Non-Liable. For each sample, the table reports the estimated coefficient of Treat * Post in regressions on Assets, Tangibles, and Employees.

\footnotetext{
${ }^{13}$ Although the 2 nd-stage dependent variable is bivariate, a linear model appears the best alternative because in large samples estimates from a LPM closely approximate marginal effects (Angrist and Pischke, 2008). In addition, 2SLS with a LPM in the second stage requires fewer assumptions regarding the distribution of the endogenous variable than alternative limited dependent variable models with endogenous regressors (Dong et al., 2012).
} 
Table 3: Impact on size (Treated vs. Control Groups)

\begin{tabular}{|c|c|c|c|c|c|c|}
\hline & \multicolumn{3}{|c|}{ Untreated } & \multicolumn{3}{|c|}{ Business Group } \\
\hline & Assets & Tangibles & Employees & Assets & Tangibles & Employees \\
\hline Treat $*$ Post & $\begin{array}{c}0.108^{* * *} \\
(0.004)\end{array}$ & $\begin{array}{c}0.042^{* * *} \\
(0.004)\end{array}$ & $\begin{array}{c}-0.066^{* * *} \\
(0.003)\end{array}$ & $\begin{array}{c}0.041^{* * *} \\
(0.009)\end{array}$ & $\begin{array}{c}0.078^{* * *} \\
(0.009)\end{array}$ & $\begin{array}{l}-0.002 \\
(0.007)\end{array}$ \\
\hline$R^{2}$ & 0.952 & 0.954 & 0.945 & 0.950 & 0.957 & 0.944 \\
\hline \multirow[t]{3}{*}{$N$} & 849,284 & 837,302 & 731,814 & 430,505 & 429,739 & 416,895 \\
\hline & \multicolumn{3}{|c|}{ Large } & \multicolumn{3}{|c|}{ Non-Liable } \\
\hline & Assets & Tangibles & Employees & Assets & Tangibles & Employees \\
\hline Treat $*$ Post & $\begin{array}{c}-0.013^{*} \\
(0.007)\end{array}$ & $\begin{array}{c}0.039^{* * *} \\
(0.008)\end{array}$ & $\begin{array}{c}-0.049^{* * *} \\
(0.006)\end{array}$ & $\begin{array}{c}0.119^{* * *} \\
(0.004)\end{array}$ & $\begin{array}{c}0.037^{* * *} \\
(0.004)\end{array}$ & $\begin{array}{c}-0.076^{* * *} \\
(0.003)\end{array}$ \\
\hline$R^{2}$ & 0.954 & 0.961 & 0.948 & 0.925 & 0.922 & 0.909 \\
\hline$N$ & 416,648 & 417,748 & 404,604 & 791,665 & 769,360 & 672,786 \\
\hline
\end{tabular}

A general pattern emerges when examining the signs of the estimated parameters across the four samples. Moving from the pre-reform to the post-reform period, treated firms experienced a larger positive change in total assets and capital vis-à-vis different untreated groups but a larger reduction in employment. ${ }^{14}$ Hence, the results lend support to the fiscal literature's prediction of a positive effect of lower taxation on capital investment. Instead, the negative coefficient in regressions on Employees is interpreted as evidence that the reform encouraged substitution of capital for labour and a technological shift towards more capital-intensive modes of production. On the basis of the graphical evidence presented in figure 2, estimates from the 'Non-liable' sample are preferred. ${ }^{15}$ These findings suggest that the reform caused an $11 \%$ increase in total assets, a $4 \%$ increase in capital assets and an $8 \%$ decrease in employment as the average effect on the group of treated firms.

\footnotetext{
${ }^{14}$ The only exception to this pattern being the positive but weakly significant coefficient on Treat $*$ Post in the regression on Assets when treated companies are compared with large companies.

${ }^{15}$ Because of the large size of the group of non-liable firms relative to the other control groups, estimates from the 'Non-liable' sample are very similar to those obtained from the 'Untreated' sample.
} 
Table 4: Impact on size (within Treated)

\begin{tabular}{|c|c|c|c|c|c|c|}
\hline & \multicolumn{3}{|c|}{$\Delta E A T R$} & \multicolumn{3}{|c|}{$\Delta E M T R$} \\
\hline & Assets & Tangibles & Employees & Assets & Tangibles & Employees \\
\hline$\triangle E A T R *$ Post & $\begin{array}{l}3.114^{* * *} \\
(0.264)\end{array}$ & $\begin{array}{l}0.786^{* *} \\
(0.326)\end{array}$ & $\begin{array}{c}-0.728^{* * *} \\
(0.219)\end{array}$ & & & \\
\hline$\Delta E M T R *$ Post & & & & $\begin{array}{c}0.564^{* * *} \\
(0.043)\end{array}$ & $\begin{array}{l}0.102^{*} \\
(0.054)\end{array}$ & $\begin{array}{c}-0.131^{* * *} \\
(0.036)\end{array}$ \\
\hline$R^{2}$ & 0.880 & 0.899 & 0.885 & 0.880 & 0.899 & 0.885 \\
\hline$N$ & 243,908 & 240,707 & 238,451 & 243,908 & 240,707 & 238,451 \\
\hline
\end{tabular}

Table 4 reports the estimated parameters of the second model (equation 2) when using the sample of small eligible firms. From a qualitative perspective, the results from the first DiD model are confirmed, but these estimates suggest a quantitatively stronger impact of the reform compared to those obtained in the first exercise. Here, the change in the statutory rate from 0.33 to 0.15 entails a mean $\triangle E A T R$ of approximately 0.15 (table 2 , firms below the threshold). The estimated parameters suggest that a company experiencing such a reduction increases total assets and capital by $47 \%$ and $11 \%$, respectively, while it decreases employment by $11 \%$. The mean $\triangle E M T R$ is 0.06 , and for such a change in marginal taxation, the estimated effect on total assets, capital and employment is $3 \%, 0.6 \%$ and $-0.8 \%$, respectively.

The different impact of effective tax gains $\triangle E A T R$ and $\triangle E M T R$ on firm size is related to the different distortions that CT exerts on firms' choice of 'discrete' and 'marginal' investment. Because EATR measures the impact of taxation on the infra-marginal return on capital, its reduction is related to firms' decision to undertake indivisible investment projects (e.g., buying a new piece of machinery, establishing a new production line) that are often related to a substantial change in production technology. Conversely, a reduction in EMTR increases the return of the 'marginal' investment and is associated with firms expanding existing projects (Devereux and Griffith, 1999). Therefore, most of the treatment effect on firm size is explained by the reduction in EATR: by expecting higher infra-marginal returns on investment, small firms implement new projects that also increase their capital intensity. 


\subsection{Indirect impact on export status}

Tables 5 and 6 present estimates from 2SLS regressions on export status Exp where the DiD models on Tangibles are used in the first stage to capture capital variations explained by the exogenous fiscal shock. Consistent with the results presented in the previous section, the interaction Treat $*$ Post is a strong instrument for Tangibles, as revealed by the high values of the Kleibergen-Paap Wald $F$ statistics. Table 5 reports a positive impact of capital on export status when comparing treated firms to any of the control groups. Specifically, a $10 \%$ increase in firm capital increases the probability of exporting to approximately $3-4 \%$, except for the Large sample where it increases to approximately $9 \%$. The larger estimated parameter in this sample may be an indication that policies promoting capital growth among domestic companies have an heterogeneous effect on export participation across firms with different initial size (this hypothesis is investigated more formally in the next subsection). According to the first- and second-stage estimates from the Untreated sample, the reform caused a $1.4 \%$ increase in export probability through the capital channel. ${ }^{16}$

Table 5: 2SLS on export status (Treated vs. Control Groups)

\begin{tabular}{|c|c|c|c|c|c|c|c|c|}
\hline & \multicolumn{2}{|c|}{ Untreated } & \multicolumn{2}{|c|}{ Business Group } & \multicolumn{2}{|c|}{ Large } & \multicolumn{2}{|c|}{ Non-Liable } \\
\hline & Exp & Tangibles & $\operatorname{Exp}$ & Tangibles & Exp & Tangibles & Exp & Tangibles \\
\hline Tangibles & $\begin{array}{c}0.361^{* * *} \\
(0.053)\end{array}$ & & $\begin{array}{c}0.450^{* * *} \\
(0.068)\end{array}$ & & $\begin{array}{c}0.934^{* * *} \\
(0.232)\end{array}$ & & $\begin{array}{c}0.315^{* * *} \\
(0.056)\end{array}$ & \\
\hline $\begin{array}{l}\text { Instrument } \\
\text { Treat } * \text { Post }\end{array}$ & & $\begin{array}{c}0.041^{* * *} \\
(0.004)\end{array}$ & & $\begin{array}{c}0.080^{* * *} \\
(0.010)\end{array}$ & & $\begin{array}{c}0.037^{* * *} \\
(0.008)\end{array}$ & & $\begin{array}{c}0.037^{* * *} \\
(0.004)\end{array}$ \\
\hline $\begin{array}{l}R^{2} \\
N \\
F\end{array}$ & $\begin{array}{l}824,754 \\
284.876\end{array}$ & $\begin{array}{c}0.125 \\
824,754\end{array}$ & $\begin{array}{l}418,415 \\
103.699\end{array}$ & $\begin{array}{c}0.118 \\
418,415\end{array}$ & $\begin{array}{c}405,723 \\
52.438\end{array}$ & $\begin{array}{c}0.129 \\
405,723\end{array}$ & $\begin{array}{l}767,999 \\
331.600\end{array}$ & $\begin{array}{c}0.130 \\
767,999\end{array}$ \\
\hline
\end{tabular}

Notes.Cluster-robust standard errors in parentheses (cluster unit: firm). All models control for firm FE and year FE. 2SLS with firm-level FE is implemented in Stata with the user-written command xtivreg2 (Schaffer, 2005). F is the Kleibergen-Paap Wald rk F statistic that is used to test for weak instruments in the first stage. Significance levels: ***.01, **.05, *.1. We exclude the years 2001 and 2002 from the estimation because they are transition years between the "old" and "new" tax regimes.

Table 6 reports the results obtained from estimating the 2SLS model on the sub-sample of treated firms with pre-reform average profits below $€ 38,120$. Results are reported for two different

\footnotetext{
${ }^{16}$ The $1.4 \%$ average increase in export probability is obtained multiplying by 100 the product of the coefficient of Treat $*$ Post on Tangibles (0.04) from the first-stage model and the coefficient of Tangibles on Exp (0.36) from the second-stage model.
} 
specifications, in the first, Tangibles is instrumented by $\triangle E A T R *$ Post and in the second by $\triangle E M T R *$ Post. Among the smallest firms, the effect of a capital increase on export status is also positive but more heterogeneous than in the previous samples, as revealed by the large associated standard error. Heterogeneity may arise due to non-linearity in the relationship between capital and export status, for example if the marginal unit of capital exerts a positive impact on export probability when capital is above a minimum threshold. This last hypothesis is tested in the following section.

Table 6: 2SLS on export status (within Treated)

\begin{tabular}{|c|c|c|c|c|}
\hline & \multicolumn{2}{|c|}{$\Delta E A T R$} & \multicolumn{2}{|c|}{$\Delta E M T R$} \\
\hline & $\operatorname{Exp}$ & Tangibles & $\operatorname{Exp}$ & Tangibles \\
\hline Tangibles & $\begin{array}{c}0.429^{*} \\
(0.226)\end{array}$ & & $\begin{array}{c}0.633^{*} \\
(0.357)\end{array}$ & \\
\hline $\begin{array}{l}\text { Instrument } \\
\Delta E A T R * \text { Post }\end{array}$ & & $\begin{array}{c}0.788^{* * *} \\
(0.305)\end{array}$ & & \\
\hline$\Delta E M T R *$ Post & & & & $\begin{array}{l}0.102^{* *} \\
(0.051)\end{array}$ \\
\hline$R^{2}$ & & 0.106 & & 0.106 \\
\hline$N$ & 240,621 & 240,621 & 240,621 & 240,621 \\
\hline$F$ & 77.900 & & 61.025 & \\
\hline $\begin{array}{l}\text { Notes. Cluster-robust } \\
\text { models control for fir } \\
\text { mented in Stata with } \\
\text { is the Kleibergen-Paa } \\
\text { ments in the first sta } \\
\text { the years } 2001 \text { and } 20 \\
\text { between the "old" and }\end{array}$ & $\begin{array}{l}\text { andard erro } \\
\text { FE and ye } \\
\text { he user-writ } \\
\text { Wald rk F s } \\
\text { e. Significar } \\
\text { 2 from the es } \\
\text { "new" tax r }\end{array}$ & $\begin{array}{l}\text { S in parenthese } \\
\text { in FE. 2SLS wi } \\
\text { en command xt } \\
\text { atistic that is u. } \\
\text { ce levels: ***. } \\
\text { imation becaus } \\
\text { gimes. }\end{array}$ & $\begin{array}{l}\text { (cluster un } \\
\text { h firm-level } \\
\text { vreg2 (Schaf } \\
\text { d to test for } \\
\text { * }^{*} .05, * .1 . \\
\text { they are tre }\end{array}$ & $\begin{array}{l}: \text { firm). All } \\
\mathrm{E} \text { is imple- } \\
\text { er, 2005).F } \\
\text { weak instru- } \\
\text { We exclude } \\
\text { asition years }\end{array}$ \\
\hline
\end{tabular}

\subsection{Heterogeneous treatment effect}

In the trade literature, productivity has been identified as the key determinant of firms' selection into exporting (e.g., Melitz, 2003; Bernard et al., 1995). However, regressions of productivity on export status can be hardly given a causal interpretation because of endogeneity arising from omitted variable bias and reverse causality. For this reason, productivity is omitted from the benchmark specification. It can be argued that given the correlation between capital and productivity, the omission of the latter from the right-hand side would bias the estimated coefficient 
on Tangibles in a standard OLS regression of export status. ${ }^{17}$ Even if the instrumental variable strategy addresses this problem, the coefficient of Tangibles should not be interpreted as the effect of firm size on export participation because it may also capture the productivity-enhancing channel of capital.

An alternative specification of the 2SLS model that controls for total factor productivity $(T f p)$ addresses this concern. ${ }^{18}$ It also includes Age (in logs) and $A g e^{2}$ to control for variations and non-linearities in the evolution of capital over the firm life cycle and Employees to absorb the indirect effect of the fiscal reform on employment. Table 7 reports the results from estimating this specification on the four samples with treated and untreated firms. After controlling for productivity, age and employment, the estimated impact of the reform on capital in the firststage equations increases from approximately $4 \%$ to nearly $6 \%$ when the model is estimated on our preferred sample (i.e, Non-Liable) and on the sample including all untreated firms (i.e., Untreated). The second-stage coefficients on Tangibles from both the Untreated and the NonLiable are not statistically different from those obtained in models that exclude the additional covariates (see table 5) and correspond to an increase in export probability of $1.4 \%$ due to the capital channel.

Consistent with previous studies reporting that exporters are more capital-intensive than non-exporters, the estimated coefficient of Employees is negative conditional on firms' capital (Bernard and Jensen, 2004; Fabling and Sanderson, 2013). As expected, Tfp is positively correlated with export status. The productivity premium of exporters (5-6\%) is slightly lower than that reported by the ISGEP study for France (7.6\%, see ISGEP, 2008). The probability of exporting is negatively associated with firm age in a non-linear way.

The results are more sensitive to the inclusion of additional controls when 2SLS models for Exp are estimated within the group of treated firms with pre-reform average profits below $€ 38,120$ (table 8). One possible explanation is that among the smallest companies, the impact of the reform on capital and export is more heterogeneous than that found in samples of larger

\footnotetext{
${ }^{17}$ The correlation between capital and productivity may arise if a positive shock in productivity leads to a higher optimal level of capital or if productivity gains are triggered by the acquisition of more advanced equipment and machinery.

${ }^{18}$ Total factor productivity is estimated by the Levinsohn-Petrin method (Levinsohn and Petrin, 2003). The production function is estimated separately for different 2-digit industries using the log of firm total sales as the dependent variable and the log expenditure on intermediate inputs to control for productivity shocks.
} 
Table 7: 2SLS on export status including controls (Treated vs. Control Groups)

\begin{tabular}{|c|c|c|c|c|c|c|c|c|}
\hline & \multicolumn{2}{|c|}{ Untreated } & \multicolumn{2}{|c|}{ Business Group } & \multicolumn{2}{|c|}{ Large } & \multicolumn{2}{|c|}{ Non-liable } \\
\hline & $\operatorname{Exp}$ & Tangibles & $\operatorname{Exp}$ & Tangibles & $\operatorname{Exp}$ & Tangibles & $\operatorname{Exp}$ & Tangibles \\
\hline Tangibles & $\begin{array}{c}0.327^{* * *} \\
(0.040)\end{array}$ & & $\begin{array}{c}0.956^{* * *} \\
(0.227)\end{array}$ & & $\begin{array}{c}4.142 \\
(3.161)\end{array}$ & & $\begin{array}{c}0.251^{* * *} \\
(0.036)\end{array}$ & \\
\hline$T f p$ & $\begin{array}{c}0.055^{* * *} \\
(0.003)\end{array}$ & $\begin{array}{c}0.018^{* * *} \\
(0.005)\end{array}$ & $\begin{array}{c}0.062^{* * *} \\
(0.007)\end{array}$ & $\begin{array}{c}0.012^{* *} \\
(0.006)\end{array}$ & $\begin{array}{c}0.073^{* * *} \\
(0.026)\end{array}$ & $\begin{array}{l}-0.000 \\
(0.006)\end{array}$ & $\begin{array}{c}0.057^{* * *} \\
(0.002)\end{array}$ & $\begin{array}{l}0.008^{*} \\
(0.005)\end{array}$ \\
\hline Employees & $\begin{array}{c}-0.062^{* * *} \\
(0.012)\end{array}$ & $\begin{array}{c}0.310^{* * *} \\
(0.004)\end{array}$ & $\begin{array}{c}-0.316^{* * *} \\
(0.088)\end{array}$ & $\begin{array}{c}0.387^{* * *} \\
(0.005)\end{array}$ & $\begin{array}{l}-1.483 \\
(1.171)\end{array}$ & $\begin{array}{c}0.371^{* * *} \\
(0.005)\end{array}$ & $\begin{array}{c}-0.036^{* * *} \\
(0.010)\end{array}$ & $\begin{array}{c}0.288^{* * *} \\
(0.004)\end{array}$ \\
\hline Age & $\begin{array}{c}-0.192^{* * *} \\
(0.026)\end{array}$ & $\begin{array}{c}0.654^{* * *} \\
(0.008)\end{array}$ & $\begin{array}{c}-0.617^{* * *} \\
(0.156)\end{array}$ & $\begin{array}{c}0.683^{* * *} \\
(0.012)\end{array}$ & $\begin{array}{l}-2.836 \\
(2.198)\end{array}$ & $\begin{array}{c}0.694^{* * *} \\
(0.012)\end{array}$ & $\begin{array}{c}-0.147^{* * *} \\
(0.024)\end{array}$ & $\begin{array}{c}0.663^{* * *} \\
(0.008)\end{array}$ \\
\hline$A g e^{2}$ & $\begin{array}{c}0.033^{* * *} \\
(0.004)\end{array}$ & $\begin{array}{c}-0.110^{* * *} \\
(0.001)\end{array}$ & $\begin{array}{c}0.103^{* * *} \\
(0.026)\end{array}$ & $\begin{array}{c}-0.114^{* * *} \\
(0.002)\end{array}$ & $\begin{array}{c}0.472 \\
(0.366)\end{array}$ & $\begin{array}{c}-0.115^{* * *} \\
(0.002)\end{array}$ & $\begin{array}{c}0.025^{* * *} \\
(0.004)\end{array}$ & $\begin{array}{c}-0.112^{* * *} \\
(0.002)\end{array}$ \\
\hline \multicolumn{9}{|l|}{ Instrument } \\
\hline Treat $_{i} *$ Post & & $\begin{array}{c}0.055^{* * *} \\
(0.004)\end{array}$ & & $\begin{array}{c}0.037^{* * *} \\
(0.008)\end{array}$ & & $\begin{array}{c}0.010 \\
(0.007)\end{array}$ & & $\begin{array}{c}0.057^{* * *} \\
(0.004)\end{array}$ \\
\hline$R^{2}$ & & 0.259 & & 0.278 & & 0.281 & & 0.257 \\
\hline$N$ & 679,423 & 679,423 & 386,340 & 386,340 & 375,036 & 375,036 & 633,040 & 633,040 \\
\hline$F$ & 252.720 & 3195.590 & 57.216 & 1918.179 & 4.406 & 1952.208 & 287.165 & 2996.869 \\
\hline
\end{tabular}

companies. The augmented specification helps to control for such heterogeneity, as is evident from the smaller standard error of the second-stage coefficient of Tangibles (table 8 vs. table 6). Because the parameters are estimated more precisely in the augmented specification, these coefficients are adopted to infer the average treatment effect of the reform on small firms' capital and export status. Among these companies, the change in the statutory rate from 0.33 to 0.15 is associated with an average change in EATR of 0.15 ( table 2). In turn, this average reduction of EATR causes an average increase in capital assets of $29 \%$ and a $6 \%$ greater probability of exporting. The mean 0.06 reduction in EMTR is instead associated with only a $2 \%$ increase in capital and a $0.5 \%$ increase in export participation. Estimates from this specification confirm that the reduction in infra-marginal taxation is the primary cause of the increase in capital and export participation for small firms.

Building on previous results, the final exercise investigates the extent to which heterogeneity in the treatment effect of the reform can be explained by initial size and productivity. To do so, we compare the firms' pre-reform average value of Tangibles and $T f p$ to the 2-digit 
Table 8: 2SLS on export status including controls (within Treated)

\begin{tabular}{|c|c|c|c|c|}
\hline & \multicolumn{2}{|c|}{$\triangle E A T R$} & \multicolumn{2}{|c|}{$\Delta E M T R$} \\
\hline & Exp & Tangibles & $\operatorname{Exp}$ & Tangibles \\
\hline Tangibles & $\begin{array}{c}0.206^{* * *} \\
(0.075)\end{array}$ & & $\begin{array}{c}0.249^{* * *} \\
(0.077)\end{array}$ & \\
\hline$T f p$ & $\begin{array}{c}0.074^{* * *} \\
(0.004)\end{array}$ & $\begin{array}{c}0.020^{* *} \\
(0.008)\end{array}$ & $\begin{array}{c}0.073^{* * *} \\
(0.004)\end{array}$ & $\begin{array}{l}0.019^{* *} \\
(0.008)\end{array}$ \\
\hline Employees & $\begin{array}{l}-0.022 \\
(0.027)\end{array}$ & $\begin{array}{c}0.356^{* * *} \\
(0.006)\end{array}$ & $\begin{array}{l}-0.038 \\
(0.028)\end{array}$ & $\begin{array}{c}0.356^{* * *} \\
(0.006)\end{array}$ \\
\hline Age & $\begin{array}{c}-0.098^{*} \\
(0.053)\end{array}$ & $\begin{array}{c}0.712^{* * *} \\
(0.017)\end{array}$ & $\begin{array}{c}-0.129^{* *} \\
(0.055)\end{array}$ & $\begin{array}{c}0.713^{* * *} \\
(0.017)\end{array}$ \\
\hline$A g e^{2}$ & $\begin{array}{l}0.017^{*} \\
(0.009)\end{array}$ & $\begin{array}{c}-0.118^{* * *} \\
(0.003)\end{array}$ & $\begin{array}{l}0.022^{* *} \\
(0.009)\end{array}$ & $\begin{array}{c}-0.118^{* * *} \\
(0.003)\end{array}$ \\
\hline \multicolumn{5}{|l|}{ Instrument } \\
\hline$\Delta E A T R *$ Post & & $\begin{array}{c}1.931^{* * *} \\
(0.268)\end{array}$ & & \\
\hline$\Delta E M T R *$ Post & & & & $\begin{array}{c}0.304^{* * *} \\
(0.045)\end{array}$ \\
\hline$R^{2}$ & & 0.249 & & 0.249 \\
\hline$N$ & 229,478 & 229,478 & 229,478 & 229,478 \\
\hline$F$ & 120.056 & 1030.500 & 114.620 & 1030.267 \\
\hline $\begin{array}{l}\text { Notes. Cluster-robust } \\
\text { firm). All models cont } \\
\text { level FE is implement } \\
\text { xtivreg2 (Schaffer, } 20 \\
\text { statistic that is used t } \\
\text { Significance levels: ** } \\
\text { and } 2002 \text { from the e } \\
\text { between the "old" and }\end{array}$ & $\begin{array}{l}\text { andard error } \\
\text { l for firm FE } \\
\text { d in Stata w } \\
5) . \quad F \text { is the } \\
\text { test for weak } \\
.01, * * .05, * \\
\text { imation beca } \\
\text { "new" tax re }\end{array}$ & $\begin{array}{l}\text { in parentheses } \\
\text { and year FE. 2 } \\
\text { th the user-wri } \\
\text { Kleibergen-Pa } \\
\text { instruments in } \\
\text { We exclude } \\
\text { ise they are tr } \\
\text { imes. }\end{array}$ & $\begin{array}{l}\text { (cluster unit: } \\
\text { LS with firm- } \\
\text { en command } \\
\text { o Wald rk F } \\
\text { he first stage. } \\
\text { ee years } 2001 \\
\text { nsition years }\end{array}$ & \\
\hline
\end{tabular}


industry median. Firms are divided into four groups: small and low-productivity (Group 1), large and low-productivity (Group 2), large and high-productivity (Group 3) and small and highproductivity (Group 4) firms. 2SLS models are separately estimated for each of these groups, comparing the treated companies to all untreated firms. The results are reported in table 9 .

Table 9: 2SLS on export status by initial productivity/size (Treated vs. Untreated)

\begin{tabular}{|c|c|c|c|c|c|c|c|c|}
\hline & \multicolumn{2}{|c|}{$\begin{array}{c}\text { Group } 1 \\
\text { (Small-Low prod) }\end{array}$} & \multicolumn{2}{|c|}{$\begin{array}{c}\text { Group } 2 \\
\text { (Large-Low prod) }\end{array}$} & \multicolumn{2}{|c|}{$\begin{array}{c}\text { Group } 3 \\
\text { (Large-High prod) }\end{array}$} & \multicolumn{2}{|c|}{$\begin{array}{c}\text { Group } 4 \\
\text { (Small-High prod) }\end{array}$} \\
\hline & $\operatorname{Exp}$ & Tangibles & Exp & Tangibles & $E x p$ & Tangibles & $E x p$ & Tangibles \\
\hline Tangibles & $\begin{array}{l}-4.165 \\
(4.866)\end{array}$ & & $\begin{array}{c}0.749 \\
(0.595)\end{array}$ & & $\begin{array}{l}0.124^{*} \\
(0.070)\end{array}$ & & $\begin{array}{c}0.091^{* * *} \\
(0.014)\end{array}$ & \\
\hline $\begin{array}{l}\text { Instrument } \\
\text { Treat } * \text { Post }\end{array}$ & & $\begin{array}{l}-0.007 \\
(0.008)\end{array}$ & & $\begin{array}{c}0.010 \\
(0.007)\end{array}$ & & $\begin{array}{l}0.051^{* * *} \\
(0.007)\end{array}$ & & $\begin{array}{l}0.260^{* * *} \\
(0.010)\end{array}$ \\
\hline $\begin{array}{l}R^{2} \\
N \\
F\end{array}$ & $\begin{array}{c}213,137 \\
9.331\end{array}$ & $\begin{array}{c}0.176 \\
213,137\end{array}$ & $\begin{array}{c}166,195 \\
6.043\end{array}$ & $\begin{array}{c}0.045 \\
166,195\end{array}$ & $\begin{array}{l}227,298 \\
37.235\end{array}$ & $\begin{array}{c}0.079 \\
227,298\end{array}$ & $\begin{array}{l}217,509 \\
167.163\end{array}$ & $\begin{array}{c}0.221 \\
217,509\end{array}$ \\
\hline $\begin{array}{l}\text { Notes.Cluster-rob } \\
\text { firm-level FE is in } \\
\text { rk F statistic that } \\
\text { years } 2001 \text { and } 20 \\
1: \text { small and low- } \\
\text { and high-product }\end{array}$ & $\begin{array}{l}\text { t standard } \\
\text { lemented ir } \\
\text { used to te } \\
2 \text { from the } \\
\text { oductivity; } \\
\text { ty. }\end{array}$ & $\begin{array}{l}\text { errors in parentl } \\
\text { Stata with the } \\
\text { st for weak instr } \\
\text { estimation beca } \\
\text { Group 2: large }\end{array}$ & $\begin{array}{l}\text { es (cluste } \\
\text { er-written } \\
\text { nents in t } \\
\text { e they are } \\
\text { d low-proc }\end{array}$ & $\begin{array}{l}\text { unit: firm). Al } \\
\text { ommand xtivr } \\
\text { first stage. Si } \\
\text { ransition year } \\
\text { ctivity; Group }\end{array}$ & $\begin{array}{l}\text { hodels contr } \\
2 \text { (Schaffer, } \\
\text { ificance lev } \\
\text { petween the } \\
\text { large and }\end{array}$ & $\begin{array}{l}1 \text { for firm } \mathrm{FE} \mathrm{a} \\
005) . F \text { is the } \\
\text { s: ***.01, **.0 } \\
\text { "old" and "new } \\
\text { igh-productivit }\end{array}$ & $\begin{array}{l}\text { year FE. } 2 \\
\text { leibergen-Pa } \\
* .1 \text {. We exc } \\
\text { tax regimes } \\
\text { and Group }\end{array}$ & $\begin{array}{l}\text { S with } \\
\text { Wald } \\
\text { ade the } \\
\text { Group } \\
\text { small }\end{array}$ \\
\hline
\end{tabular}

A significant and positive effect on Tangibles and Exp is found only for Groups 3 and 4. Because these two groups include the more productive $50 \%$ of firms in the sample, it can be concluded that a CT reduction has a significant impact on capital accumulation and export status only on relatively more productive firms. It is conceivable that when taxation is reduced, highproductivity firms expand their set of profitable investment opportunities significantly more than do low-productivity firms. In addition, the treatment effect of the reform on Tangibles is much stronger for productive and small firms (Group 4) than it is for productive and large firms (Group 3). Hence, a CT reduction appears to be particularly effective in removing obstacles to the growth of small and productive companies. 


\section{Conclusion}

This study generates novel and robust evidence on the effectiveness of fiscal policy to promote SMEs' capital growth and, through this channel, export participation. Specifically, we analysed the effects of a reduction in corporate taxation for small and medium enterprises. A positive impact on capital and export status is found when comparing the evolution of these variables between treated and untreated companies after the introduction of the policy and when investigating the heterogeneous gains from the policy within the group of treated firms.

The results suggest that the impact of this policy is heterogeneous across firms. When evaluated on the entire group of eligible companies, the average treatment effect of the reform on capital assets and export probability is $+6 \%$ and $+1.4 \%$, respectively. In turn, it increases to $+29 \%$ and $+6 \%$, respectively, when these effects are estimated on the subgroup of treated firms with average pre-reform profits below $€ 38,120$. The findings also indicate that the impact of the reform is conditional on firms' initial productivity. It can be concluded that a reduction in the rate of corporate taxation is an effective policy to promote the capital growth and the exports of more productive small companies.

Some caveats are in order. First, the empirical strategy adopted in this study does not identify the precise mechanism through which capital growth fosters greater export entry: the results are consistent with both a productivity-enhancing channel à la Melitz (2003) and with a size channel as in Blum et al. (2013). Second, while the reform was effective in promoting capital growth, it also appears to generate a substitution of capital for labour. Our tentative interpretation of this result is that lower taxation on profits may induce the adoption of more capital-intensive production techniques. This preliminary evidence of labour substitution calls for further research to understand the technological implications of CT reductions.

\section{References}

Altomonte, C., Acquilante, T. and Ottaviano, G. (2012). The triggers of competitiveness: The EFIGE cross-country report. Bruegel. 
Angrist, J. D. and Pischke, J.-S. (2008). Mostly Harmless Econometrics: An Empiricist's Companion. Princeton University Press, 1st edn.

Arnold, J. M., Brys, B., Heady, C., Johansson, A., Schwellnus, C. and Vartia, L. (2011). Tax policy for economic recovery and growth. The Economic Journal, 121 (550), F59-F80.

Bernard, A. and Jensen, B. (1999). Exceptional exporter performance: cause, effect, or both? Journal of International Economics, 47 (1), 1-25.

Bernard, A. B. and Jensen, J. B. (2004). Why some firms export? The Review of Economics and Statistics, 86 (2), 561-569.

—, - and LaWrence, R. Z. (1995). Exporters, jobs, and wages in U.S. manufacturing: 19761987. Brookings Papers on Economic Activity. Microeconomics, 1995, pp. 67-119.

Blum, B. S., Claro, S. and Horstmann, I. J. (2013). Occasional and perennial exporters. Journal of International Economics, 90 (1), 65-74.

Bond, S. and XING, J. (2010). Corporate taxation and capital accumulation. Working Paper 10/15, Oxford University Centre for Business Taxation.

Costantini, J. A. and Melitz, M. J. (2008). The dynamics of firm-level adjustment to trade. In D. M. Elhanan Helpman and T. Verdier (eds.), The Organization of Firms in a Global Economy, Cambridge MA: Harvard University Press.

Devereux, M. P. and Griffith, R. (1999). The taxation of discrete investment choices. IFS Working Paper W98/16, Institute for Fiscal Studies.

— and — (2003). Evaluating tax policy for location decisions. International Tax and Public Finance, 10 (2), 107-26.

—, - and Klemm, A. (2002). Corporate income tax reforms and international tax competition. Economic policy, 17 (35), 449-495.

DGI (2002). Bulletin Officiel des mpôts. Tech. rep., Direction Générale des Impôts. 
Dong, Y., Lewbel, A. and Yang, T. T. (2012). Comparing Features of Convenient Estimators for Binary Choice Models With Endogenous Regressors. Boston College Working Papers in Economics 789, Boston College Department of Economics.

Egger, P., Loretz, S., Pfaffermayr, M. and Winner, H. (2009). Firm-specific forwardlooking effective tax rates. International Tax and Public Finance, 16 (6), 850-870.

Fabling, R., Gemmell, N., Kneller, R. and Sanderson, L. (2013). Estimating Firm-Level Effective Marginal Tax Rates and the User Cost of Capital in New Zealand. Treasury Working Paper Series 13/29, New Zealand Treasury.

— and SAnderson, L. (2013). Exporting and firm performance: market entry, investment and expansion. Journal of International Economics, 89 (2), 422-431.

Hicks, J. R. (1932). The Theory of Wages. London: Macmillan.

ISGEP (2008). Understanding cross-country differences in exporter premia: comparable evidence for 14 countries. Review of World Economics (Weltwirtschaftliches Archiv), 144 (4), 596-635.

King, M. A. and Fullerton, D. (1984). The taxation of income from capital: a comparative study of the United States, the United Kingdom, Sweden, and Germany. NBER Books.

Levinsohn, J. and Petrin, A. (2003). Estimating Production Functions Using Inputs to Control for Unobservables. Review of Economic Studies, 70 (2), 317-341.

McKenzie, K., Mansour, M. and Brule, A. (1998). The Calculation of Marginal Effective Tax Rates. Working paper 97-15, Dept. of Finance, Canada. Technical Committee on Business Taxation.

Melitz, M. J. (2003). The impact of trade on intra-industry reallocations and aggregate industry productivity. Econometrica, 71 (6), 1695-1725.

OECD (1994). Taxation and Small Businesses. OECD. 
RASPILleR, S. (2007). Reduced-rate corporation tax for SMEs. Tresor Economics 23, Tresor Economics.

Schaffer, M. E. (2005). Xtivreg2: Stata module to perform extended iv/2sls, gmm and ac/hac, liml and k-class regression for panel data models. Statistical Software Components, Boston College Department of Economics.

Vartia, L. (2008). How do Taxes Affect Investment and Productivity?: An Industry-Level Analysis of OECD Countries. OECD Economics Department Working Papers 656, OECD Publishing.

WAGNER, J. (2007). Exports and productivity: A survey of the evidence from firm-level data. The World Economy, 30 (1), 60-82. 


\section{Appendix}

\section{A1. Computation of the effective tax rates}

This section describes the methodology to compute the firm-specific marginal and average effective rates of taxation, EMTR and EATR. The EMTR measures the distortion that taxation induces on investment as the difference between the return of capital at the margin with taxation $(\tilde{p})$ and without taxation (the opportunity cost of capital, $\bar{r}$ ):

$$
E M T R_{i}=\frac{\tilde{p}_{i}-\bar{r}}{\tilde{p}_{i}}
$$

According to the formulation of Devereux and Griffith (2003), $\tilde{p}_{i}$ is computed as:

$$
\tilde{p}_{i}=\frac{1-A_{i}}{(1-\tau)(1-i n)}\left[i+\delta_{i}(1+i n)-i n\right]-\frac{F(1+i)}{(1+\tau)(1+i n)}-\delta_{i}
$$

where $\bar{r}$ is the average real return of capital (set at 0.05 following Egger et al., 2009), in is the inflation rate and $i$ is the nominal interest rate (and firms' opportunity cost). We compute $i=[(1+r)(1+i n)-1]$ using the long-term interest rates for $r$, and the year-to-year change of the consumer price index for $i n$, where $r$ and in are both obtained from OECD data. The parameter $\tau$ is the statutory CT rate. Eventually, $A_{i}$ and $\delta_{i}$ are two firm-specific variables that measure respectively the net present value of the depreciation allowances per unit of investment, and the economic depreciation of firms' assets. Following the approach of Egger et al. (2009), we obtain $A_{i}$ and $\delta_{i}$ as:

$$
\begin{gathered}
A_{i}=A_{m} * \theta_{m i}+A_{b} * \theta_{b i}+A_{I} * \theta_{I i} \\
\delta_{i}=\delta_{m} * \theta_{m i}+\delta_{b} * \theta_{b i}+\delta_{i} * \theta_{I i}
\end{gathered}
$$

where $\theta_{m i}, \theta_{b i}$ and $\theta_{I i}$ are the shares of machineries, buildings and intangibles over the total assets of firm $i$. FICUS data provide information on the composition of firms' assets into tangible and intangible. To disaggregate further tangible assets into buildings and machineries, we rely on industry shares obtained from McKenzie et al. (1998). $A_{m}, A_{b}$ and $A_{I}$ are the net present values 
of depreciation allowances calculated with asset-specific linear depreciation rates as reported in the French law. ${ }^{19} \delta_{m}=0.1225, \delta_{b}=0.0361$ and $\delta_{i}=0.15$ are the standard parameters used in the tax literature for the economic depreciation of machineries, buildings and intangibles. Firms' financial structure (i.e., the proportion of debt financing) enters into the computation of the $E M T R$ through the term $F$ in equation 5:

$$
F= \begin{cases}0, & \text { if investment is self-financed } \\ \frac{(1-\tau \delta)[i-i(1-\tau)]}{1+i}, & \text { if investment is financed through debt; }\end{cases}
$$

Eventually, the effective marginal tax rate $E M T R_{i}$ of firm $i$ is calculated as:

$$
E M T R_{i}=E M T R_{s i} *\left(1-\operatorname{lev}_{i}\right)+E M T R_{d i} *\left(l e v_{i}\right)
$$

where $E M T R_{s i}$ is the rate obtained by assuming complete self-financing, $E M T R_{d i}$ is the one obtained by assuming complete debt-financing, and $l e v_{i}$ is the proportion of debt financing of firm $i$ computed as the debt share over total assets. Because we are interested in evaluating the impact of the reform on firms that are ex-ante different in terms of assets and financial structure, we use firm-level pre-reform averages of $l e v_{i}$ and $A_{i}$, instead of their yearly values. This is done to isolate the change in effective taxation caused by a change in statutory rates from the changes happening through different channels (i.e., asset composition or financial structure).

Following Devereux and Griffith (2003), the EATR instead represents the gap between the net present value (NPV) of an investment project in the presence of taxation $\left(R_{i}\right)$ or without $\left(R^{*}\right)$ :

$$
E A T R_{i}=\frac{R^{*}-R_{i}}{p /(1+r)}
$$

where $R_{i}$ and $R^{*}=\frac{p-r}{1+r}$ are respectively the NPV of the investment with and without tax, and $p=0.2$ is the standard parametrization of the pre-tax real return of capital (Egger et al., 2009). $R$ is computed as follows:

$$
R=(1-i)^{-1}\left\{(1+i n)(i+\delta)(1-\tau)-\left(1-A_{i}\right)\left[(1+i)-(1+i n)\left(1-\delta_{i}\right)\right]\right\}+F
$$

\footnotetext{
${ }^{19}$ Bulletin Officiel des Finances Publiques, bofip.impots.gouv.fr/bof ip/4520-PGP?datePubl=17/04/2013.
} 
As for the EMTR, the firm-specific return to investment $R_{i}$ is calculated as a weighted average of $R$ in case of self-financing and in case of debt-financing. The firm-specific value $E A T R_{i}$ is eventually obtained as in equation 6 .

\section{A2. Data information}

Table 10: Data cleaning.

\begin{tabular}{lcc}
\hline \hline & Nb. of observations \\
\hline Original data & $1,901,891$ & \\
& & $-261,475$ \\
Drop if the firm changes treatment category & $-36,179$ \\
Drop if non-liable firm has a positive tax expense & & \\
Data after cleaning & $1,604,237$ & \\
Drop if the firm is not present before & & $-498,473$ \\
and after the reform & & \\
Final sample & $1,105,764$ & \\
\hline \hline
\end{tabular}

Table 11: Computation of the main variables

\begin{tabular}{ll}
\hline \hline Name & Description \\
\hline Tangibles & Deflated book value of tangible assets, in logs \\
Exp & Binary variable, firms with positive foreign sales \\
Assets & Deflated book value of total assets, in logs \\
Employees & Number of employees, in logs \\
Capital Intensity & Ratio of deflated tangible assets over the total number of hours worked, in logs \\
Age & Age +1, in logs \\
Labour prod & Ratio of deflated value added over the total number of hours worked, in logs \\
Tfp & Method: Levinsohn and Petrin $(2003)$ \\
$($ Backward) Tax rate & Ratio of corporate tax expenses over total gross profit. \\
elo & Identifier for 'Business group' control group \\
elc & Identifier for 'Large' control group (total sales $>€ 7,630,000)$ \\
elj & Identifier for 'Non-liable' control group (based on legal status) \\
Treat & Eligibility dummy: $=1$ if elj=1, elo=1 and elc $=1,0$ otherwise \\
Post & Reform dummy: = 1 if $t>2002,0$ otherwise \\
\hline \hline
\end{tabular}

Note. Variables are deflated at the 2-digit level using information provided by INSEE. 